\title{
Energetic Efficiency of the Vegetable Waste Used as Substrate for Biogas Production
}

\author{
Damian Janczak ${ }^{1}$ Kamil Kozłowski ${ }^{1}$, Zbyszek Zbytek$^{2}$, Marta Cieślik ${ }^{3}$, Artur Bugała ${ }^{4}$, and Wojciech Czekała ${ }^{1}$ \\ ${ }^{1}$ Institute of Biosystems Engineering, Poznan University of Life Sciences, ul. Wojska Polskiego 28 60-637 Poznan, Poland \\ ${ }^{2}$ Industrial Institute of Agricultural Engineering, ul. Starolecka 31 60-963 Poznan, Poland \\ ${ }^{3}$ Department of Biotechnology and Food Microbiology, Poznan University of Life Sciences, Wojska Polskiego 48, 60-637 Poznan, Poland \\ ${ }^{4}$ Institute of Electrical Engineering and Electronics, Poznan University of Technology, ul. Piotrowo 3a, 60-965 Poznan, Poland
}

\begin{abstract}
Different vegetable waste materials (beetroot leaves, turnip leaves, yellow beans, onion waste), commonly found in Central Poland were tested for estimation of energy efficiency while methane fermentation process. The results showed that the biggest green mass of vegetable waste harvested from field was related to the highest water content. In contrary, the higher methane production from $1 \mathrm{Mg}$ of tested biowaste was obtained in case of the materials with the highest dry mass content (yellow beans and onion waste, 28.03 and $44.33 \mathrm{~m}^{3} \mathrm{Mg}^{-1}$ ). Although the onion waste was the lowest fermented substrate, however the energy yield for this material is visibly the highest $\left(4435 \mathrm{kWh} \mathrm{ha}^{-1}\right)$ among all tested ones.
\end{abstract}

\section{Introduction}

Growing demand for electricity and heat as a result of economic development and increasing environmental pollution due to the use of fossil fuels (mainly coal) forced the mankind to look for alternative energy carriers. Hence, in recent years, the use of environment-friendly technologies i.e. renewable sources, had a significantly growing interest [1-3]. Implementation of renewable energy sources (RES) in recent years can be also related to a rational waste management and generally increasing emphasis on environmental protection [4-5]. The most important advantage of renewable energy is the fact that RES are inexhaustible and renewed naturally.

One of the RES type is the energy used from biomass. Besides the pellets, briquetting, pyrolysis and direct combustion, the biomass is used as a substrate for biogas plants [6-7]. Those installations can produce the electricity and heat, and moreover allow to utilize the waste materials from crop production [8].

The biogas market in Europe is growing rapidly, wherein the essential substrates for installations are maize silage and animal faeces [9-10]. There have been observed new efforts and attempts to use the alternative substrates, including technologically advanced materials i.e. algae [6-11]. In Poland, with low support for each produced energy unit - MWe el, building the biogas plant installation with technology based on substrates from dedicated crops is highly unprofitable. Production of $1 \mathrm{~kg}$ of maize silage costs about 120-150 PLN, which is too high price, taking into account the fact that in Poland, the average price for produced electricity is approx. 3 times lower than in Germany. The advantage of a biogas plant is that it can use plant waste materials or waste from fruit and vegetable processing [12]. This fact may cause the development of the biogas market in Poland, since there are many regions producing millions of tons of organic waste from agriculture and agri-food industry. It should be noted that after joining the EU in 2004, Poland received large financial resources for investments in the both agricultural and food processing sector. As a result, there were implemented very modern solutions promoting the efficiency of agricultural production, food processing, even including those based on the use of artificial intelligence techniques [13-15], and image analysis [16-20]. Moreover, for environmental friendly processing of bio-waste many actions have been taken on a large scale. The fastest growing technology was the biowaste composting [21-26]. However, it should be highlighted that methane fermentation of bio-waste ensures effective processing and also enables efficient production of biogas and in further consequence electricity and heat [27]. In order to make a biogas plant a profitable investment, already planning the whole construction, a suitable substrate should be selected, which will be a year-round feedstock for biogas plants [28]. The most common substrate used in biogas plants in Europe is maize silage [29]. Promising substrates for biogas production are vegetable waste materials generated during the production and processing of field vegetables, such as beetroot leaves, turnip greens, yellow beans and husk onion. Like so far there are no biogas plants in Poland using waste generated during the production of field vegetables.

This will be certainly a good alternative for current management of these waste materials, which are 
distributed across the fields for fertilizing purposes special permit required. Another method to manage those waste is composting process $[25,30]$ however in this case - except the obtained fertilizer - the economy effect of the technology is negative. Taking into account the "waste-to-energy" idea, it can be stated that use of vegetable waste for energy production is a good direction for management of the waste of this kind.

\section{Aim and the range of research}

The aim of this study was to examine the biogas productivity of waste from typical agricultural vegetables as well as to analyze the energetic potential of those biowaste materials in case of use as a substrate in biogas plant. Because of the low support for electric energy production from RES in Poland, the main possibility to keep the positive economic balance for biogas plants is to avoid the usage of typical but expensive plants (i.e. maize or rye silage) and look for cheaper substrates like agricultural residues. The following research objectives have been formulated:

to analyze the potential of biogas production from different biowaste based on vegetable waste materials;

to calculate the energy value of the vegetable waste used in biogas production process.

\section{Materials and methods of research}

The analyzed materials were collected from the agricultural farms specialized in vegetable production. These farms are placed in south of Wielkopolska Region (Central Poland) which is the center of Polish vegetable production. The amount of vegetable waste materials in this area produced by farms and agro-food industry exceeds yearly over 1 million $\mathrm{Mg}$, which directly shows the importance of this problem. Actually, this situation is mainly solved by spreading the biowaste on the fields which is often forbidden by Polish legislation.

The following vegetable waste materials have been tested:

- beetroot leaves,

- turnip leaves,

- yellow beans,

- onion waste (including rinds).

The research tests were made in the Laboratory of Ecotechnologies (which is the biggest Polish biogas laboratory), placed in the Institute of Biosystems Engineering, at the Poznan University of Life Sciences (PULS). The methodology of measurement and the biogas production calculations were made in accordance with the following norms: DIN 38 414/S8 and VDI 4630. The physical and chemical analyzes were made according to the Polish standard systems: dry matter content under Polish standard norm PN-75C-04616/01 (drying by $24 \mathrm{~h}$ in $105^{\circ} \mathrm{C}$ ), organic dry matter according to the norm PNZ-15011-3 (combustion of the samples in $525^{\circ} \mathrm{C}$ by 3 hours).

The fermentation set-up consisted of 21 biofermentors. Each individual biofermentor (made from glass) had a volume of $2 \mathrm{dm}^{3}$. The special design of the biofermentor as well as the whole position has kept the experiments under anaerobic conditions. The process was carried out under mesophilic conditions at $39^{\circ} \mathrm{C}+/-1^{\circ} \mathrm{C}$. The scheme of experimental set-up for biogas fermentation is shown in Figure 1.

The produced biogas in each biofermentor chamber was transported via teflon pipe to the gas reservoir. These reservoirs were made from plexiglass as an inverted cylinder immersed in water. Between the water and gas areas, there was a liquid barrier preventing the dissolution of $\mathrm{CO}_{2}$ in the water. According to the DIN norm, all samples were tested in triplicate.

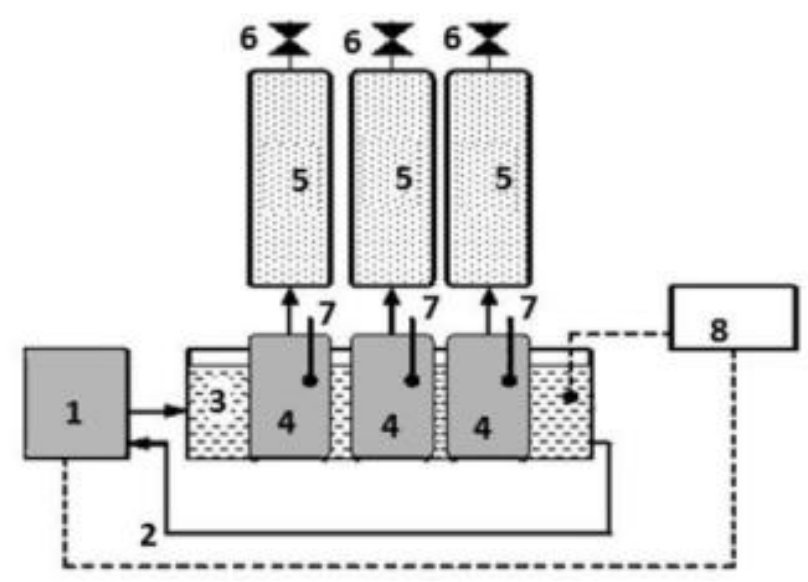

Figure 1. Scheme of biofermenter for biogas production research (3-chamber section). 1: Water heater with temperature regulator, 2: insulated conductors of calefaction liquid, 3: water coat with temperature $39 \mathrm{oC}, 4$ : biofermentor with charge capacity $2 \mathrm{dm} 3,5$ : biogas reservoir, 6 : cutting off valves, 7 : sampling tubes, 8 : recording central station.

\section{Results}

\subsection{The potential of biogas production}

Before taking the samples for analyzing biogas efficiency, the estimation of vegetable waste yield has been made. The results are shown in Table 1.

Table 1. The parameters of the tested material.

\begin{tabular}{|l|c|}
\hline Type of biowaste & $\begin{array}{c}\text { Harvested mass } \\
{\left[\mathbf{M g}^{*} \mathbf{h a}^{-\mathbf{1}}\right]}\end{array}$ \\
\hline Beetroot leaves & 25 \\
\hline Turnip leaves & 20 \\
\hline Yellow beans & 10 \\
\hline Onion waste & 14 \\
\hline
\end{tabular}

The presented results show that the biggest productivity is in case of beetroot leaves $\left(25 \mathrm{Mg} \mathrm{ha}^{-1}\right)$. However, the dry mass (T.S.) concentration as well as organic matter content (V.S.) is quite low for this biowaste (Table 2). This suggests that energy efficiency of this material can be lower comparing to the other kinds of biowaste - with higher level of dry mass.

The initial analysis of all tested biowaste is shown in Table 2 . 
Table 2. The basic parameters of tested biowaste: Dry mass (T.S.), organic dry mass (V.S.) and $\mathrm{pH}$.

\begin{tabular}{|l|c|c|c|}
\hline \multicolumn{1}{|c|}{ Type of biowaste } & $\begin{array}{c}\text { T.S. } \\
{[\%]}\end{array}$ & $\begin{array}{c}\text { V.S. } \\
{[\%]}\end{array}$ & $\begin{array}{c}\mathrm{pH} \\
{[-]}\end{array}$ \\
\hline Beetroot leaves & 9.68 & 71.30 & 6.61 \\
\hline Turnip leaves & 8.93 & 82.00 & 6.08 \\
\hline Yellow beans & 11.77 & 93.97 & 5.45 \\
\hline Onion waste & 28.13 & 72.81 & 8.49 \\
\hline
\end{tabular}

Except the onion waste, all materials were characterized by low content of dry matter. In all cases, the dry matter concentration was significantly lower comparing to maize straw - the most popular substrate for biogas production in Central Europe. The concentration of organic matter was high in all cases, which was favourable for methane fermentation.

Table 3. The biogas and biomethane production from fresh mass of analysed biowaste.

\begin{tabular}{|l|c|c|c|}
\hline $\begin{array}{l}\text { Type of } \\
\text { biowaste }\end{array}$ & $\begin{array}{c}\mathrm{CH}_{4} \text { content } \\
{[\%]}\end{array}$ & $\begin{array}{c}\mathrm{CH}_{4} \text { yield } \\
{\left[\mathrm{m}^{3} \mathrm{Mg}^{-1}\right]}\end{array}$ & $\begin{array}{c}\text { Biogas yield } \\
{\left[\mathrm{m}^{3} \mathrm{Mg}^{-1}\right]}\end{array}$ \\
\hline Beetroot leaves & 52.61 & 17.63 & 33.51 \\
\hline Turnip leaves & 46.10 & 23.90 & 51.84 \\
\hline Yellow beans & 46.89 & 28.03 & 59.79 \\
\hline Onion waste & 51.34 & 44.33 & 86.36 \\
\hline
\end{tabular}

As it was expected, because of higher content of dry mass, the highest biogas and biomethane productivity was found in case of onion waste. Even the highest methane concentration was observed for beetroot leaves $(52.61 \%)$, the total production of biomethane was the lowest $\left(17.63 \mathrm{~m}^{3} \mathrm{Mg}^{-1}\right)$.

It should be also underlined, that the dynamics of the biogas production was different for all tested biowaste materials (Figure 2).

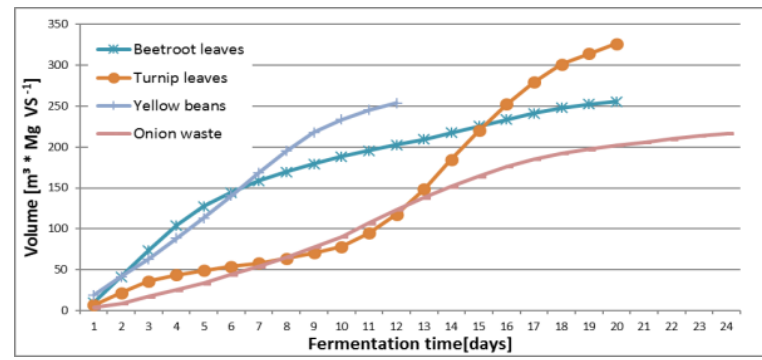

Figure 2. Cumulative production of methane from $1 \mathrm{Mg}$ of VS of tested materials.

The results showed on Fig. 2 proved considerable differences in fermentation time (HRT) for tested materials. Yellow beans waste has the shortest HRT period which is favourable for intensive exploitation of biogas plant installation. Onion waste is the worst material (among tested) in terms of intensity of biogas production and duration of fermentation.

\subsection{Energetic analysis}

The comparison of tested biowaste energy yield based on biomass harvested from the fields and biogas production efficiency is shown in Table 4.
Table 4. Energy yield of analysed biowaste.

\begin{tabular}{|l|c|c|c|c|}
\hline Sample & $\begin{array}{c}\mathrm{CH}_{4} \text { yield } \\
{\left[\mathrm{m}^{3} \mathrm{Mg}^{-1}\right]}\end{array}$ & $\begin{array}{c}\mathrm{EEP}^{*} \\
{\left[\mathrm{kWh} \mathrm{Mg}^{-1}\right]}\end{array}$ & $\begin{array}{c}\text { Mass yield } \\
{\left[\mathrm{Mg}^{*} \mathrm{ha}^{-1}\right]}\end{array}$ & $\begin{array}{c}\text { Energy yield } \\
{\left[\mathrm{kWh} \mathrm{ha}^{-1}\right]}\end{array}$ \\
\hline $\begin{array}{l}\text { Beetroot } \\
\text { leaves }\end{array}$ & 33.51 & 0.123 & 25 & 3073 \\
\hline $\begin{array}{l}\text { Turnip } \\
\text { leaves }\end{array}$ & 51.84 & 0.19 & 20 & 3803 \\
\hline $\begin{array}{l}\text { Yellow } \\
\text { beans }\end{array}$ & 59.79 & 0.219 & 10 & 2193 \\
\hline $\begin{array}{l}\text { Onion } \\
\text { waste }\end{array}$ & 86.36 & 0.317 & 14 & 4435 \\
\hline
\end{tabular}

* Electric Energy Potential, energetic value of $1 \mathrm{Mg}$ of fresh mass, calculated as $\mathrm{CH}_{4}$ volume multiplied by energetic value of $\mathrm{CH}_{4}\left(9.17 \mathrm{kWh} \mathrm{m}^{-3}\right)$ and electric energy coefficient of cogeneration unit $(40 \%)$

The comparison of tested biowaste shows that the best energy yield was noted in case of onion waste $(4435 \mathrm{kWh}$ $\mathrm{ha}^{-1}$ ) and the lowest for yellow beans waste (2193). Those values however are visibly lower comparing to the energy yield of typical agricultural substrate in Europe - maize silage $\left(16836 \mathrm{kWh} \mathrm{ha}^{-1}\right)$. From economical point of view, the analyzed substrates are offered for free, or for the cost of transport, comparing to maize silage with the high price 27-50 Euro/Mg. Thus, utilization of the aforementioned waste materials seems to be better from economic reasons, even the biogas productivity is lower.

\section{Conclusions}

The research experiments described in this paper led us to the following conclusions:

- According to the results shown in Tables 1 and 2, the biggest fresh mass of vegetable waste (beetroot leaves) harvested from field was related to the highest water content. However, the highest harvested dry matter amount was in case of onion waste.

- The higher methane production from $1 \mathrm{Mg}$ of tested biowaste was obtained in the case of the materials with the highest dry mass content (yellow beans and onion waste, 28.03 and $44.33 \mathrm{~m}^{3} \mathrm{Mg}^{-1}$ ).

- The onion waste was the lowest fermenting substrate, based on fresh mass calculation, however the energy yield for this material is visibly the highest $(4435 \mathrm{kWh}$ $\mathrm{ha}^{-1}$ ) among all tested materials.

- The energy yield of the best tested material (onion waste) is almost 4 times lower than in case of maize silage (16836 $\left.\mathrm{kWh} \mathrm{ha}^{-1}\right)$, however high price of maize silage in Central Europe (27-50 Euro/Mg) makes this material less attractive without important subsidies for biogas production.

\section{References}

1. W. Czekała, K. Kozłowski, J. Dach, P. Boniecki, A. Lewicki, D. Janczak, K. Jóźwiakowski, T. Piechota, Energy Conversion from Biomass to Hydrogen and Methane. 4th International Conference on Materials Engineering for Advanced Technologies (ICMEAT) Location: London, England, pp. 654-657 (2015)

2. J.P. Maity, J. Bundschuh, C-Y. Chen, P. Bhattacharya, Microalgae for third generation biofuel 
production, mitigation of greenhouse gas emissions and wastewater treatment: Present and future perspectives - A mini review. Energy 78, 104-113 (2014)

3. J. Dach, K. Koszela, P. Boniecki, M. Zaborowicz, A. Lewicki, W. Czekała, J. Skwarcz, Q. Wei, H. Piekarska-Boniecka, I. Białobrzewski, The use of neural modeling to estimation the methane production from slurry fermentation processes. Renewable and Sustainable Energy Reviews 56, 603-610 (2016)

4. D. Janczak, M. Marciniak, A. Lewicki, W. Czekała, K. Witaszek, P.C. Rodríguez Carmona, M. Cieślik, J. Dach, Bioreactor Internet System for Experimental Data Monitoring and Measurement, Procedia Technology 8, 209-214 (2013)

5. K. Malińska, M. Zabochnicka-Świątek, J. Dach, Effects of biochar amendment on ammonia emission during composting of sewage sludge. Ecological Engineering 71, 474-478 (2014)

6. A. Lewicki, J. Dach, D. Janczak, W. Czekala, The experimental macro photoreactor for microalgae production, Procedia Technology 8, 622-627 (2013)

7. F. Dong, J. Lu, Using solar energy to enhance biogas production from livestock residue - A case study of the Tongren biogas engineering pig farm in South China. Energy 57, 759-765 (2013)

8. Q. Xinshan, Z. Shuping, W. Yuzhi, W. Renqing, Advantages of the integrated pig-biogas-vegetable greenhouse system in North China. Ecological Engineering 24, 177-185 (2005)

9. J. Dach, W. Czekała, P. Boniecki, A. Lewicki, T. Piechota, Specialised Internet Tool for Biogas Plant Modelling and Marked Analysing. Advanced Materials Research 909, 305-310 (2014)

10. A. Lewicki, P. Boniecki, J. Dach, D. Janczak, W. Czekała, Z. Zbytek, M. Cieślik, Neural Estimation of Biomethane Efficiency from Maize Silage, Maize Straw and Cattle Slurry. 4th International Conference on Materials Engineering for Advanced Technologies (ICMEAT) Location: London, (2015)

11. S. Cerbin, K. Nowakowski, J. Dach, K. Pilarski, P. Boniecki, J. Przybyl., A. Lewicki, Possibilities of neural image analysis implementation in monitoring of microalgae production as a substrate for biogas plant. 4th International Conference On Digital Image Processing (ICDIP 2012). Proceedings of SPIE 8334 (2012)

12. S. Berlian, Sukandar, D. P. Seno, Biogas recovery from anaerobic digestion process of mixed fruit vegetable wastes. International Conference on Sustainable Energy Engineering and Application. Energy Procedia 32, 176-182 (2013)

13. P. Boniecki, K. Nowakowski, R. Tomczak, S. Kujawa, H. Piekarska-Boniecka, The application of the Kohonen neural network in the non-parametric quality-based classification of tomatoes. 4th International Conference on Digital Image Processing. Kuala Lumpur (Malaysia), proceedings of SPIE, 8334, (2012)

14. W. Czekała, J. Dach, A. Ludwiczak, A. Przybylak, P. Boniecki, K. Koszela, M. Zaborowicz, K. Przybył, D.
Wojcieszak, The use of image analysis to investigate $\mathrm{C}: \mathrm{N}$ ratio in the mixture of chicken manure and straw. Proc. SPIE. 9631, Seventh International Conference on Digital Image Processing (ICDIP 2015), 963117 (2015)

15. P. Boniecki, H. Piekarska-Boniecka, K. Koszela, M. Zaborowicz, K. Przybył, D. Wojcieszak, Z. Zbytek, A. Ludwiczak, A. Przybylak, A. Lewicki, Neural classifier in the estimation process of maturity of selected varieties of apples. Proc. SPIE. 9631, Seventh International Conference on Digital Image Processing (ICDIP 2015), 963115 (2015)

16. S. Kujawa, R.J. Tomczak, T. Kluza, J. Weres, P. Boniecki, A stand for the image acquisition of composted material based on the sewage sludge. 4th International Conference on Digital Image Processing. Kuala Lumpur (Malaysia), proceedings of SPIE, 8334 (2012)

17. K. Nowakowski, P. Boniecki, R.J. Tomczak, S. Kujawa, B. Raba, Identification of malting barley varieties using computer image analysis and artificial neural networks. 4th International Conference on Digital Image Processing. Kuala Lumpur (Malaysia), proceedings of SPIE, 8334 (2012)

18. D. Janczak, A. Lewicki, R. Mazur, P. Boniecki, J. Dach, J. Przybyl, M. Pawlak, K. Pilarski, W. Czekala, The Selected Examples of the Application of Computer Image Analysis in the Assessment of Environmental Quality. 5th International Conference on Digital Image Processing. Beijing (China), proceedings of SPIE, $\mathbf{8 8 7 8}$ (2013)

19. K. Przybył, K. Koszela, P. Boniecki, W. Mueller, B. Raba, A. Lewicki, Organoleptic Damage Classification of Potatoes with the Use of Image Analysis in Production Process, Proc. SPIE 9159, Sixth International Conference on Digital Image Processing (ICDIP 2014) (2014).

20. B. Raba, K. Nowakowski, A. Lewicki, K. Przybył, M. Zaborowicz, K. Koszela, P. Boniecki, The Nontouching Method of the Malting Barley Quality Evaluation. Proc, SPIE 9159, Sixth International Conference on Digital Image Processing (ICDIP 2014) (2014)

21. A. Wolna-Maruwka, J. Dach, Effect of Type and Proportion of Different Structure-Creating Additions on the Inactivation Rate of Pathogenic Bacteria in Sewage Sludge Composting in a Cybernetic Bioreactor. Archives of Environmental Protection. 35, 3 87-100 (2009)

22. K. Malińska, M. Zabochnicka-Świątek, Selection of bulking agents for composting of sewage sludge. Environment Protection Engineering 39, 2 91-103 (2013)

23. 23. A. Piotrowska-Cyplik, Ł. Chrzanowski, P. Cyplik, J. Dach, A. Olejnik, J. Staninska, J. Czarny, A. Lewicki, R. Marecik, J. Powierska-Czarny, Composting of oiled bleaching earth: Fatty acids degradation, phytotoxicity and mutagenicity changes. International Biodeterioration \& Biodegradation. 78 49-57 (2013)

24. K. Koszela, J. Otrząsek, M. Zaborowicz, P. Boniecki, W. Mueller, B. Raba, A. Lewicki, K. Przybył, 
Quality Assessment of Microwave-vacuum Dried Material with the Use of Computer Image Analysis and Neural Model, Proc. SPIE 9159, Sixth International Conference on Digital Image Processing (ICDIP 2014) (2014)

25. A. Lewicki, J. Dach, P. Boniecki, W. Czekała, K. Witaszek, The Control of Air Humidity and Temperature in Relationship with a Biowaste Composting Process. Advanced Materials Research 909 455-462 (2014)

26. I. Białobrzewski, M. Mikš-Krajnik, J. Dach, M. Markowski., W. Czekała, K. Głuchowska, Model of the sewage sludge-straw composting process integrating different heat generation capacities of mesophilic and thermophilic microorganisms. Waste Management 43 72-83 (2015)

27. J. Dach, P. Boniecki., J. Przybył, D. Janczak, A. Lewicki, W. Czekała, K. Witaszek, P.C. Rodríguez
Carmona, M. Cieślik, Energetic efficiency analysis of the agricultural biogas plant in $250 \mathrm{kWe}$ experimental installation. Energy 69 34-38 (2014)

28. M. Lebuhn, A. Hanreich, M. Klocke, A. Schlüter, C. Bauer, C. Pérez, Towards molecular biomarkers for biogas production from lignocellulose-rich substrates. Anaerobe, 29 10-21 (2014)

29. E. Bruni, A.P. Jensen, E.S. Pedersen, I. Angelidaki, Anaerobic digestion of maize focusing on variety, harvest time and pretreatment. Applied Energy. 87 2212-2217 (2010)

30. J. Starzyk, W. Czekała, The Influence of Admixtures Accelerating the Pine Bark Composting Process on Variation in the Bacteriological State of Composts. Archives of Environmental Protection 40, 4, 125 135 (2014) 